\title{
Evaluation of Fungicide for the Management of Leaf and Fruit Spot (Phaeoramularia angolensis) of Sweet Orange in West \& Kellem Wollaga Zones
}

\author{
Abay Guta $^{1} \quad$ Zawdu Tegenu ${ }^{2} \quad$ Kibru Kena ${ }^{3}$ \\ Oromia Agricultural Research Institute, Haro Sabu research center, Haro Sabu, KellemWollega, Ethiopia
}

\begin{abstract}
Sweet orange (Citrus sinensis) is an important fruit crop in the daily diet, good source of food nutrients, cash to the farmers. The leaf and fruit spot disease caused by Phaeoramularia angolensis is one of the most devastating airborne diseases and also the main constraints contributing to the low productivity of citrus plantation in 20 African countries including Ethiopia. The experiment was conducted to evaluate three fungicide (Unizeb $80 \%$ WP, Trust-cymocop 439.5 WP, and Benomyl $500 \mathrm{WP}$ ) and combination of the two each fungicide under field conditions for the management of leaf and fruit spot disease and also to assess the yield losses. Not significant different in disease incidence between treatments and there was a significant difference in the leaf and fruit spot disease severity and Area under Disease Progressive Curve (AUDPC) among treatments. On the final date of disease assessment, among the fungicide, Unizeb sprayed was recorded the lowest disease severity (17.33\%) and $(18.17 \%)$, whereas the highest disease severity of $(46.67 \%)$ and $(45.83 \%)$ were recorded on leaf and fruit spot on control plots, respectively. The highest fruit yield of 6.14 and $5.94 \mathrm{t} / \mathrm{ha}$ were also recorded from plots sprayed with Unizeb 80\% WP and Benomyl 500 WP fungicide. Unizeb $80 \%$ WP fungicide applied exhibited maximum partial cost net benefit from all plots that means the highest $\left(123970.00 \mathrm{ETB} \mathrm{ha}^{-1}\right)$ was recorded and followed by Benomyl 500 WP $\left(111520.00 \mathrm{ETB} \mathrm{ha}^{-1}\right)$ fungicide treated plots. The results of the present study revealed that the novel possibility of using Unizeb foliar spray with four times which was found to be an effective in decreasing leaf and fruit spot disease symptoms on sweet orange in Kellem Wollega, Western Oromiya and increased yield.
\end{abstract}

Keywords: Sweet Orange, Leaf and Fruit spot disease, Fungicides, Yield and Cost benefit.

DOI: $10.7176 / \mathrm{JBAH} / 9-5-01$

Publication date:March $31^{\text {st }} 2019$

\section{Introduction}

The sweet orange (Citrus sinensis) is a member of the citrus family (Rutaceae), along with other fruits such as mandarins, lemons, grapefruits and limes. Even though citrus is a genius that contains many important species, sweet orange (Citrus sinensis) is the most important of all citrus fruits in the world (Taylor, 2008).

Globally, the leading producer of sweet oranges is Brazil followed by the European Union and China. In 2014, Brazil produced 17340 MT followed by China [7 600 MT], United States [6 291 MT], and European Union [6 075 MT]. In Africa, Egypt was leading with a production of 2570 MT followed by South Africa [1 600 MT] and Morocco [1 000 MT] (Anonymous, 2014). Similarly, in 2013 orange was one of the important fruits in Ethiopia with a total area coverage and total production of 3,000 ha and 36,000 tons respectively (FAO, 2015).

Citrus has got multiple advantages including food source, raw material for agro-industries, income generation and source of employment especially for the rural poor. The Government policy on the promotion of citrus production in Africa is quite encouraging as the sector has got attractive and multiple social and economic advantage. In tropical Africa, particularly Sub-Saharan Africa production of citrus is seriously hampered by a fungal disease caused by Phaeoramularia angolensis (Seif et al., 1984: Mohammed, 2013)

In many parts of the country, citrus productivity is threatened by a disease called Phaeoramularia leaf and fruit spot (Mohammed et al., 2007). This disease, caused by a fungus, Phaeoramularia angolensis (Covalho \& Mendes) Kirk (1986), was first reported in Angola and Mozambique in 1952. Within a short period, the disease spread northwards to the south of the Sahara (Meyonga, 1971: Emechebe, 1981: Seif, 1984). Later it spread to the eastern part of Africa: Uganda (Kirk, 1986), Kenya (Seif, 1984) and Ethiopia (Eshetu, 1999). The disease has also been reported in Yemen (Kirk, 1986). Leaf and fruit spot disease of citrus is transmitted by airborne conidia or infected planting materials (Kuate, 1998: Seif, 1998). Currently, the disease is widespread and is becoming a major threat to citrus plantation in 20 African countries including Ethiopia.

However, in a very short time, this disease was widespread in many citrus-growing areas of the country including the south, south-west, West and north-west parts of Ethiopia. The disease causes heavy loss to the citrus industry in these areas. The most devastating effect of the disease on all citrus species is premature defoliation of young leaves and fruit drop, and sunken lesions on the fruit surface, which seriously affect their market value. Infected fruits became extremely hard, juiceless and unattractive (Mohammed, 2007)

However, the management of sweet orange fruit and leaf spot disease through the effect of fungicides has not been studied so far in West and Kellem Wollega, Western Oromiya region of Ethiopia. Therefore, this study was 
carried out to evaluate the fungicides for management of fruit and leaf spot disease of sweet orange under field conditions and also to assess the economic benefit of fungicides.

\section{MATERIALS AND METHODS}

\section{Description of the study area}

The field experiment was conducted in Haro Sabu Agricultural Research Center (HSARC) Mexi Sub-site in Sayo District, Western Oromia, Ethiopia during the main cropping season of 2016 and 2017. Sayo District is located at $652 \mathrm{~km}$ West of Addis Ababa and its geographic location is $8.5333^{\circ} \mathrm{N}$ latitude and $34.80117^{\circ} \mathrm{E}$ longitude with an elevation of $1754-2200 \mathrm{~m}$. a. s. 1. The area receives high rainfall with minimum and maximum temperature of the site is $13^{\circ} \mathrm{C}$ and $27 \mathrm{oC}$, respectively and characterized by wet and humid climatic conditions where the fruit and leaf spot is known to be consistently prevalent and severe on local cultivars. The soil of the experimental study site is vertisol with light black in color and sandy loam soil type with $\mathrm{pH}$ value of 6 .

\section{Experimental materials}

Sweet orange fruit Local cultivar was planted before twenty years by Sayo district Agriculture experts for farmers training which we were used in this experimental study. Three fungicides (Trust-cymocop 439.5 WP, Benomyl $500 \mathrm{WP}$ and Unizeb 80\% WP and combination of the two each fungicide (Benomyl $500 \mathrm{WP}+$ Trust-cymocop 439.5 WP, Unizeb 80\% WP +Trust-cymocop 439.5 WP and Benomyl $500 \mathrm{WP}+$ Unizeb 80\% WP were used in this study. All the fungicides were obtained from local market.

\section{Experimental design, treatments and applications}

A total of 7 treatments were arranged in a randomized complete block design with three replications and unsprayed plot was used as a standard check. Plot size was consisted of $6 \mathrm{~m} \times 6 \mathrm{~m}$ and an inter-row and intra-row spacing of $3 \mathrm{~m}$ and $3 \mathrm{~m}$, respectively, which has 4 plants per plot. Disease assessments were carried out from 2 plants which were tagged from each plot. The fungicides were applied as per recommendation of the manufacturers using a manually-pumped knapsack sprayer of 15 liter capacity. The spraying was started soon after the first leaf spot disease lesion was observed on the foliage and continued depending on disease status. All fungicides were applied for two months at fourteen day's interval.

\section{Disease assessment}

\section{Disease incidence and severity}

Disease assessment were made on two pre-tagged plants from each plot starting from the onset of the disease and continued every ten days till fruit maturity. Both diseased and healthy plants were counted from the pre-tagged plants and the percentage of disease incidence (PDI) was calculated according to the formula used by Wheeler (1969):

$$
\operatorname{PDI}(\%)=\frac{\text { Number of plsnt diseased }}{\text { Total number of plants inspected }} \times 100
$$

Severity on leaves was estimated using the percentage leaf area infected based on a one-to-five scoring scale where $1=$ no symptoms, $2=1-25 \%, 3=26-50 \%, 4=51-75 \%$ and $5=$ above 75\% (Amadi, 2008; Ezeibekwe, 2011). A similar scoring system was used for fruit severity, where $1=$ healthy, $2=$ less than $5 \%, 3=5-20 \%, 4=21-50 \%$ and $5=$ above $50 \%$ of fruit surface affected (Seif and Hillocks, 1999). The severity grades were converted into percentage severity index (PSI) according to the formula by Wheeler (1969).

$$
\operatorname{PSI}(\%)=\frac{\sum \text { Individualnumericalratings }}{(\text { TotalnumberofplantsassessedxMaximumscoreinthescale })} \times 100
$$

\section{Area under Disease Progress Curve (AUDPC)}

The progress of leaf and fruit spot was plotted over time using to mean percentage severity index for each chemical and control plot and the AUDPC values (\%-day) were calculated for each variety according to the mid-point rule formula (Campbell and Madden, 1990).

$\mathrm{AUDPC}==\sum_{i-1}^{n-1} \mathbf{0 . 5}\left(\boldsymbol{x}_{i+1}+\boldsymbol{x}_{i}\right)\left(\boldsymbol{t}_{i+1}-\boldsymbol{t}_{i}\right)$

Where $\mathrm{Xi}$ is the disease severity of leaf and fruit spot at I th assessment date, Ti is the time of the I th assessment in days from the first assessment date and $\mathrm{n}$ is the total number of disease assessments. Because severity was in percentage and time in days, AUDPC was express in proportion days.

\section{Correlation between yield and disease parameters}

The correlations among the disease parameters and with the yield were tested at $5 \%$ probability level. The reliable yield loss was estimated on the basis of the severity level by employing regression equations.

Cost benefit analysis

The prices of fruit sweet orange (birr $/ \mathrm{kg}$ ) were assessed from the local market and the total price of the commodity obtained from each treatment was computed on hectare basis. Input costs like fungicide and labor were converted into hectare basis used. Fungicides cost was estimated based on the price of company. Cost of the labor was in Birr per man-days; cost of spray and spray equipment to spray one week time four per hectare were calculated. Cost of spray equipment (knapsack sprayer) was in Birr per day assessed. Based on the obtained data from the 
above mentioned parameters, cost benefit analysis was performed using partial budget analysis. Partial budget analysis is a method of organizing data and information about the cost and benefit of various agricultural alternatives (CIMMYT, 1988). Partial budgeting is employed to assess profitability of any new technologies (practice) to be imposed to the agricultural business. Marginal analysis is concerned with the process of making choice between alternative factor product combinations considering small changes. Marginal rate of return is a criterion which measures the effect of additional capital invested on net returns using new managements compared with the previous one (CIMMYT,1988). It provides the value of benefit obtained per the amount of additional cost incurred percentage. The formula is as follows:

$$
\mathrm{MRR}=\frac{\mathrm{DNI}}{\mathrm{DIC}} \mathrm{X} \%
$$

Where, MRR is marginal rate of returns, DNI, difference in net income compared with control, DIC, difference in input cost compared with control.

\section{Data Analysis}

The analysis of variance (ANOVA) was performed for the disease parameters (incidence, severity, AUDPC) and yields using GenStat software. Least significant difference (LSD) values were used to separate treatment means $(\mathrm{P}<0.05)$ among the treatments. Correlation coefficient $(r)$ between yield and severity were determined through yield components correlation analysis using GenStat 15 th edition software, following analysis using the standard procedure (Gomez and Gomez, 1984).

\section{RESULTS AND DISCUSSION}

\section{Disease incidence}

Phaeoramularia leaf and fruit spot disease of sweet orange was first observed at on experimental field at the beginning of august in both years (2016 and 2017) and it was recorded on the leaf of sweet orange all treatments. There was a not significant difference disease incidence between treatments for Phaeoramularia leaf and fruit spot disease of sweet orange and also no significance difference disease incidence between fungicides sprayed and unsprayed plots of the treatments.

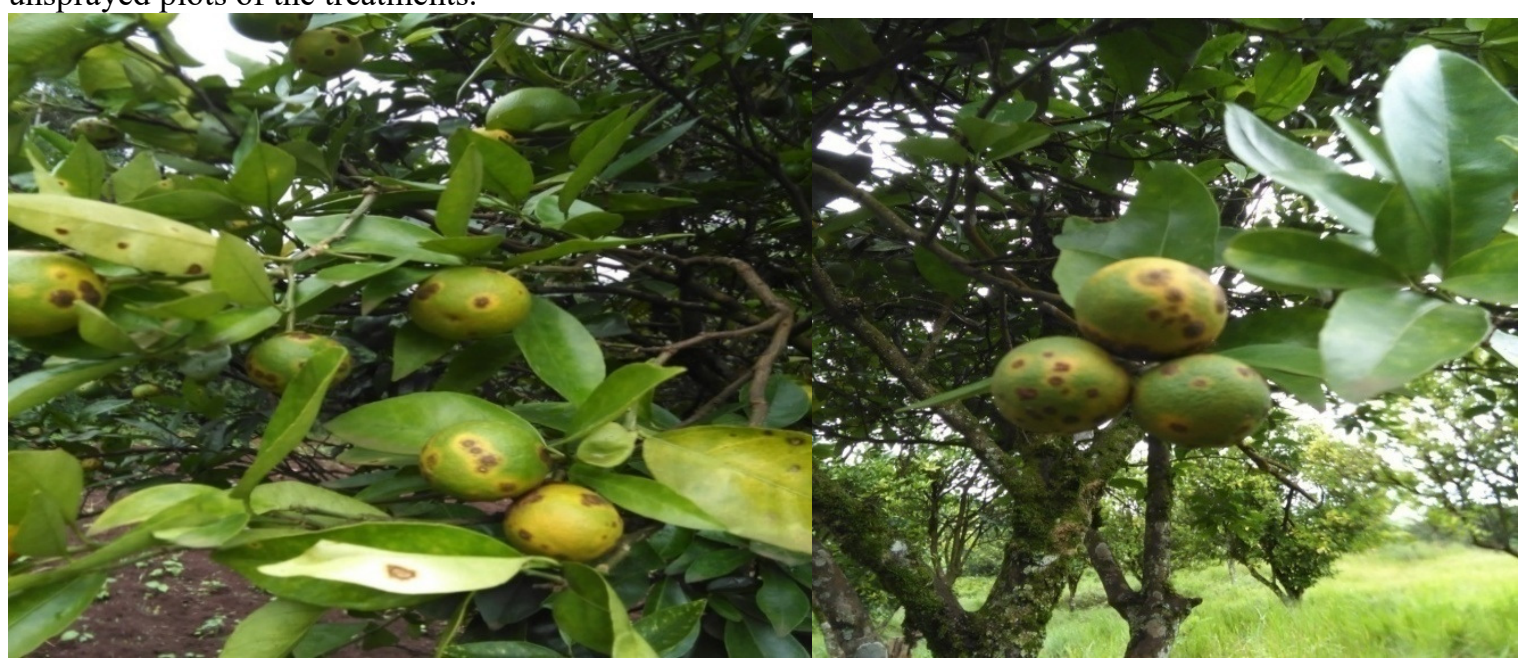

Figure 1 leaf and fruit spot disease of sweet Orange

Disease severity

The Percentage Severity index (PSI) data revealed that the severity of Phaeoramularia leaf spot on the control plot was higher than the treated plots (Table 1). Highly significant differences $(\mathrm{P}<0.05)$ Unizeb $80 \%$ WP sprayed plot were recorded at all dates of assessment. Next to Unizeb 80\% WP plot treated Benomyl 500 WP and Benomyl $500 \mathrm{WP}+$ Unizeb 80\% WP fungicides treated were significance difference from control plot Phaeoramularia leaf spot disease of sweet orange(Table 1). Variation in the disease severity of the Phaeoramularia leaf spot disease of sweet orange of Unizeb $80 \%$ sprayed (17.33\%) at last day assessment. In two years (2016 and 2017) Unizeb 80\% WP fungicide treated plot was a significant differences $(\mathrm{P}<0.05)$ Phaeoramularia leaf spot disease. However, the lowest severity leaf spot (17.33\%) was recorded on sweet orange of Unizeb $80 \%$ sprayed and the highest disease severity leaf spot $(46.67 \%)$ was assessed on Control (no sprayed) (Table 1$)$. 
Table 1: Percentage severity index of leaf spot of sweet orange treated with fungicides against leaf and fruit spot

\begin{tabular}{llllll}
\hline \multirow{2}{*}{ Fungicides } & \multicolumn{5}{c}{ Percentage diseases severity index (10 interval ) } \\
\cline { 2 - 6 } & $1 \mathrm{st}$ & 2nd & 3rd & 4th & 5 th \\
\hline Control (no sprayed) & $16.67^{\mathrm{a}}$ & $23.33^{\mathrm{a}}$ & $33.83^{\mathrm{a}}$ & $42.17^{\mathrm{a}}$ & $46.67^{\mathrm{a}}$ \\
Trust-cymocop 439.5 WP & $15.0^{\mathrm{bc}}$ & $19.33^{\mathrm{b}}$ & $25.17^{\mathrm{b}}$ & $30.67^{\mathrm{b}}$ & $34.33^{\mathrm{b}}$ \\
Benomyl 500 WP +Trust-cymocop 439.5 WP & $12.33^{\mathrm{bc}}$ & $16.67^{\mathrm{cb}}$ & $22.5^{\mathrm{bc}}$ & $26.83^{\mathrm{bc}}$ & $30.33^{\mathrm{b}}$ \\
Benomyl 500 WP & $9.5^{\mathrm{d}}$ & $14.33^{\mathrm{c}}$ & $17.67^{\mathrm{c}}$ & $21.17^{\mathrm{ed}}$ & $22.67^{\mathrm{cd}}$ \\
Unizeb 80\% WP +Trust-cymocop 439.5 WP & $10.83^{\mathrm{cd}}$ & $17.0^{\mathrm{cb}}$ & $22.5^{\mathrm{bc}}$ & $28.5^{\mathrm{bc}}$ & $30.67^{\mathrm{b}}$ \\
Benomyl 500 WP + Unizeb 80\% WP & $9.5^{\mathrm{d}}$ & $14.83^{\mathrm{c}}$ & $19.83^{\mathrm{c}}$ & $24.17^{\mathrm{cd}}$ & $27.83^{\mathrm{bc}}$ \\
Unizeb 80\% WP & $5.83^{\mathrm{e}}$ & $9.0^{\mathrm{d}}$ & $12.0^{\mathrm{d}}$ & $15.17^{\mathrm{e}}$ & $17.33^{\mathrm{d}}$ \\
\hline mean & 11.38 & 16.36 & 21.93 & 26.95 & 29.98 \\
LSD (0.05) & 2.73 & 3.83 & 4.93 & 6.07 & 7.26 \\
CV \% & 20.37 & 19.91 & 19.12 & 19.14 & 20.6 \\
\hline \hline
\end{tabular}

$\mathrm{LSD}=$ Least significant difference, $\mathrm{CV}=$ Coefficient of variations,

The Percentage Severity index (PSI) data revealed that the severity of Phaeoramularia fruit spot on the control plot was higher than the treated plots (Table 2). Highly significant differences $(\mathrm{P}<0.05)$ Unizeb 80\% WP sprayed plot were recorded at all dates of assessment. Next to Unizeb 80\% WP plot treated Benomyl 500 WP and Benomyl 500 WP + Unizeb 80\% WP fungicides treated were significance difference from control plot Phaeoramularia fruit spot starting fourth and fifth dates of disease assessments of sweet orange(Table 2). Variation in the disease severity of the Phaeoramularia fruit spot disease of sweet orange of Unizeb 80\% sprayed (18.17\%) at last day assessment. In two years Unizeb $80 \%$ WP fungicide treated plot was a significant differences $(\mathrm{P}<0.05)$ Phaeoramularia fruit spot disease. However, the lowest severity fruit spot (18.17\%) was recorded on sweet orange of Unizeb $80 \%$ sprayed and the highest disease severity fruit spot (45.83\%) was assessed on Control (no sprayed) (Table 2).

Table 2: Percentage severity index of fruit spot of sweet orange treated with fungicides against leaf and fruit spot

\begin{tabular}{llllll}
\hline \multicolumn{1}{c}{ Fungicides } & \multicolumn{5}{c}{ Percentage diseases severity index (10 interval ) } \\
\cline { 2 - 6 } & $1 \mathrm{st}$ & 2nd & 3rd & 4th & 5 th \\
\hline Control (no sprayed) & $17.83^{\mathrm{a}}$ & $22.83^{\mathrm{a}}$ & $31.33^{\mathrm{a}}$ & $38.17^{\mathrm{a}}$ & $45.83^{\mathrm{a}}$ \\
Trust-cymocop 439.5 WP & $12.67^{\mathrm{bc}}$ & $18.67^{\mathrm{b}}$ & $22.67^{\mathrm{b}}$ & $28.17^{\mathrm{bc}}$ & $33.33^{\mathrm{bc}}$ \\
Benomyl 500 WP +Trust-cymocop 439.5 WP & $14.0^{\mathrm{b}}$ & $19.0^{\mathrm{ab}}$ & $24.67^{\mathrm{b}}$ & $30.17^{\mathrm{b}}$ & $34.17^{\mathrm{b}}$ \\
Benomyl 500 WP & $11.0^{\mathrm{cd}}$ & $15.83 \mathrm{~b}$ & $20.5^{\mathrm{b}}$ & $24.83^{\mathrm{c}}$ & $26.83^{\mathrm{cd}}$ \\
Unizeb 80\% WP +Trust-cymocop 439.5 WP & $13.83^{\mathrm{b}}$ & $18.67^{\mathrm{b}}$ & $23.0^{\mathrm{b}}$ & $30.17^{\mathrm{b}}$ & $35.17^{\mathrm{b}}$ \\
Benomyl 500 WP + Unizeb 80\% WP & $10.33^{\mathrm{cd}}$ & $15.33^{\mathrm{b}}$ & $19.5^{\mathrm{b}}$ & $23.67^{\mathrm{c}}$ & $25.83^{\mathrm{d}}$ \\
Unizeb 80\% WP & $8.25^{\mathrm{d}}$ & $10.25^{\mathrm{c}}$ & $12.33^{\mathrm{c}}$ & $14.17^{\mathrm{d}}$ & $18.17^{\mathrm{e}}$ \\
\hline mean & 12.56 & 17.15 & 22 & 27.05 & 31.33 \\
LSD (0.05) & 1.48 & 3.99 & 5.41 & 5.28 & 6.92 \\
CV \% & 18.71 & 19.82 & 20.91 & 16.61 & 18.79 \\
\hline \hline
\end{tabular}

$\mathrm{LSD}=$ Least significant difference, $\mathrm{CV}=$ Coefficient of variations,

\section{Area under Disease Progress Curve (AUDPC)}

There were highly significant differences $(\mathrm{P}<0.01)$ on AUDPC of fungicide sprayed sweet orange. The analysis of variance exhibited Unizeb $80 \%$ WP fungicide sprayed was significantly different on both leaf and fruit spot AUDPC from all treatments. Next to Unizeb 80\% WP; Benomyl $500 \mathrm{WP}$ and Unizeb 80\% WP +Trust-cymocop 439.5 WP sprayed treatments were significant $(\mathrm{P}<0.05)$ on both leaf and fruit spot AUDPC from other treated but no significant difference between the two treatments (Table 3). The maximum AUDPC was calculated on control (unsprayed) plot; both leaf and fruit spot which were 1965 and 1863 (\%-day), respectively (Table 3). AUDPC values varied among the fungicide sprayed treatments and it is known that AUDPC is directly related to the yield loss (Singh and Rao, 1989). Therefore, selection of fungicide sprayed should have low AUDPC value is acceptable for practical purposes. Moreover, Jerger (2004) indicated that comparisons of disease progress curves and AUDPC between treatments are the most commonly used tools for evaluating practical disease management strategies. 
Table 3: AUDPC of leaf and fruit spot of sweet orange treated with fungicides against leaf and fruit spot

\begin{tabular}{lll}
\hline \multicolumn{1}{c}{ Fungicides } & \multicolumn{1}{c}{ AUDPC \%-days } \\
\cline { 2 - 3 } & leaf spot & fruit spot \\
\hline Control (no sprayed) & $1965^{\mathrm{a}}$ & $1863^{\mathrm{a}}$ \\
Trust-cymocop 439.5 WP & $1489^{\mathrm{b}}$ & $1496^{\mathrm{b}}$ \\
Benomyl 500 WP +Trust-cymocop 439.5 WP & $1310^{\mathrm{bc}}$ & $1469^{\mathrm{b}}$ \\
Benomyl 500 WP & $1039^{\mathrm{d}}$ & $1201^{\mathrm{c}}$ \\
Unizeb 80\% WP +Trust-cymocop 439.5 WP & $1340^{\mathrm{bc}}$ & $1329^{\mathrm{bc}}$ \\
Benomyl 500 WP + Unizeb 80\% WP & $1162^{\mathrm{cd}}$ & $1149^{\mathrm{c}}$ \\
Unizeb 80\% WP & $716^{\mathrm{e}}$ & $749^{\mathrm{d}}$ \\
\hline mean & 1289 & 1322 \\
LSD (0.05) & $297.3^{* *}$ & $342.1^{* *}$ \\
CV \% & 13.7 & 15.4 \\
\hline \hline
\end{tabular}

$\mathrm{LSD}=$ Least significant difference, $\mathrm{CV}=$ Coefficient of variations,

Total fruit yield (ton/ha)

There were highly significant differences $(\mathrm{P}<0.01)$ among treatments in total fruit yield of sweet oranges. Plots treated with Unizeb $80 \%$ WP foliar spray fungicide gave the highest total fruit yield (ton/ha) followed by Benomyl $500 \mathrm{WP}$ and Benomyl $500 \mathrm{WP}+$ Unizeb 80\% WP foliar sprayed fungicides plots(Tables 4). The highest (6.14 t $\mathrm{ha}^{-1}$ ) fruit yield was gained from Unizeb $80 \%$ WP foliar spray fungicide, where as the lowest $\left(3.42 \mathrm{t} \mathrm{ha}^{-1}\right)$ fruit yield was from control (unsprayed) plot (Table 4). Likewise, the Benomyl $500 \mathrm{WP}$ and Benomyl $500 \mathrm{WP}+\mathrm{Unizeb}$ $80 \%$ WP fungicide sprayed plots $\left(5.94 \mathrm{tha}^{-1}\right)$ and $\left(5.43 \mathrm{t} \mathrm{ha}^{-1}\right)$ next high yielder, respectively. This result is higher than average fruit yield of Kellem Wellega $\left(4.6 \mathrm{t}^{-1} \mathrm{ha}\right)$ while less than average fruit yield of national level around $7.88 \mathrm{t}^{-1}$ ha (CAS, 2017).

Table 4: Yield of sweet Orange treated with fungicides against leaf and fruit spot disease

\begin{tabular}{ll}
\hline \multicolumn{1}{c}{ Fungicides } & yield (ton/ha) \\
\hline Control (no sprayed) & $3.42^{\mathrm{e}}$ \\
Trust-cymocop 439.5 WP & $4.85^{\mathrm{cd}}$ \\
Benomyl 500 WP +Trust-cymocop 439.5 WP & $4.24^{\mathrm{de}}$ \\
Benomyl 500 WP & $5.94^{\mathrm{ab}}$ \\
Unizeb 80\% WP +Trust-cymocop 439.5 WP & $5.43^{\mathrm{bcd}}$ \\
Benomyl 500 WP + Unizeb 80\% WP & $5.82^{\mathrm{abc}}$ \\
Unizeb 80\% WP & $6.14^{\mathrm{a}}$ \\
\hline mean & 5.16 \\
LSD (0.05) & 10.8 \\
CV \% & 12 \\
\hline \hline
\end{tabular}

$\mathrm{LSD}=$ Least significant difference, $\mathrm{CV}=$ Coefficient of variations,

\section{Relative Yield loss}

Yield losses were computed relative to the average yield from plots with the maximum protection against the disease (i.e. plots with highest yield and lowest disease severity in each cultivar). Nevertheless, the fruit yield losses were reduced by all fungicides sprayed plots as compared with the unsprayed control plots (Table 5). The yield loss was significantly different $(\mathrm{P}<0.05)$ in all treatments. The highest i.e. $44.31 \%$ relative yield losses occurred on the unsprayed control treatment. The second and third highest $30.93 \%$ relative yield losses occurred on the Benomyl 500 WP +Trust-cymocop 439.5 WP and Trust-cymocop 439.5 WP fungicides sprayed plots. Relatively, lowest yield loss of $3.29 \%$ and $5.24 \%$ were recorded from plots sprayed with Benomyl 500 WP and Benomyl $500 \mathrm{WP}+$ Unizeb 80\% WP, respectively(table 5).

Table 5: Yield loss of sweet orange fruits due to leaf and fruit spot

\begin{tabular}{lllll}
\hline \multicolumn{1}{c}{ Fungicides } & \multicolumn{3}{c}{ Yield and Relative Loss } \\
\cline { 2 - 5 } & \multicolumn{1}{c}{ yield (ton/ha) } & Yield (Kg/ha) & RYL (Kg/ha) & RYL (\%) \\
\hline Control (no sprayed) & $3.42^{\mathrm{e}}$ & 3421.2 & 2722.3 & 44.31 \\
Trust-cymocop 439.5 WP & $4.85^{\text {cd }}$ & 4847.5 & 1296 & 21.09 \\
Benomyl 500 WP +Trust-cymocop 439.5 WP & $4.24^{\text {de }}$ & 4243.3 & 1900.2 & 30.93 \\
Benomyl 500 WP & $5.94^{\text {ab }}$ & 5941.2 & 202.3 & 3.29 \\
Unizeb 80\% WP +Trust-cymocop 439.5 WP & $5.43^{\text {bcd }}$ & 5430.3 & 713.2 & 11.6 \\
Benomyl 500 WP + Unizeb 80\% WP & $5.82^{\text {abc }}$ & 5821.4 & 322.1 & 5.24 \\
Unizeb 80\% WP & $6.14^{\mathrm{a}}$ & 6143.5 & 0.0 & 0.0 \\
\hline \hline
\end{tabular}

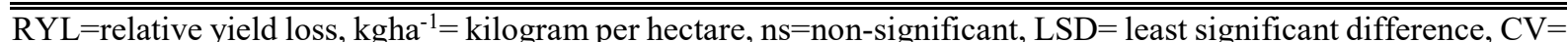
coefficient of variations, $* *=$ highly significant difference at $(\mathrm{P}<0.01), *=$ significant difference at $(\mathrm{P}<0.05)$. 


\section{Correlation between yield and disease parameters}

Correlation analysis of severity, AUDPC and yield exhibited highly significant $(\mathrm{P}<0.01)$ association with different fungicides treatments (Table 5). The severity and AUDPC values were negative but significant correlation was found between grain yields. Severity and AUDPC had highly significant negative correlation coefficients of $r=$ 0.89 and $\mathrm{r}=-0.90$ with yield, respectively, while AUDPC and severity themselves were even highly and positively $(r=0.97)$ correlated with each other (Table 5). Consequently, the result of this study indicated that the yield of the sweet orange fruit was significantly affected by disease severity that also influenced the AUDPC.

In most cases, the negative correlation of yield with disease development was found to be stronger with the terminal disease severity and AUDPC. This might indicate that the terminal disease severity and AUDPC were very important in determining the extent of losses in yield and the observed levels of the disease had a considerable adverse effect on grain yield of the crops (Sul et al., 2006).

Table 6: Coefficients (r) linear correlation between of disease parameters and yield under field conditions

\begin{tabular}{llll}
\hline & \multicolumn{1}{c}{ Correlations } & \\
\hline parameters & disease severity $\%$ & AUDPC & Yield t/ha \\
\hline Disease severity $\%$ & 1 & & \\
AUDPC & $0.97 * *$ & 1 & 1 \\
Yield t $/$ ha & $-0.89 * *$ & $-0.90^{* *}$ & 1 \\
\hline \hline
\end{tabular}

$\mathrm{AUDPC}=$ area under disease progress curve, yield $\mathrm{t} / \mathrm{ha}=$ yield tone per hectare, ${ }^{* *},{ }^{*}$, Correlation is significant at the $(\mathrm{p}<0.01)$ and $(\mathrm{P}<0.05)$ significance level, respectively and $\mathrm{ns}=$ non significant;

The regression analysis of the final severity $\left(5^{\text {th }}\right)$ as predictor with yield (dependent variable) showed a significant $(\mathrm{p} \leq 0.05)$ relationship. The regression equation of the yield $(\mathrm{t} / \mathrm{ha})=79.8-0.79 \mathrm{X},(\mathrm{r} 2=83 \%, \mathrm{p}=0.00)$ demonstrated reduction of about 0.79 t/ha fruit yield with the increase of $1 \%$ severity index of leaf spot (Figure 2). Similarly, regression analysis of the final severity $\left(5^{\text {th }}\right)$ as predictor with fruit weight (dependent variable) showed a significant $(\mathrm{P} \leq 0.01)$ relationship with severity of fruit spot. The regression equation of the fruit weight $(\mathrm{t} / \mathrm{ha})=$ 84.07-1.07X, ( $\mathrm{r} 2=88 \%, \mathrm{P}=0.00)$ demonstrated reduction of about 1.07 tone with the increase of $1 \%$ severity (Figure 2). The values of coefficient of determination (r2) explained that $88 \%$ of the losses in fruit yield were due to the effect of the sweet orange "leaf and fruit spot" disease infection of sweet orange estimated as the final severity on the yield loss (\%). (The independent variable ' $\mathrm{x}$ ' indicates the disease severity level in percentage).
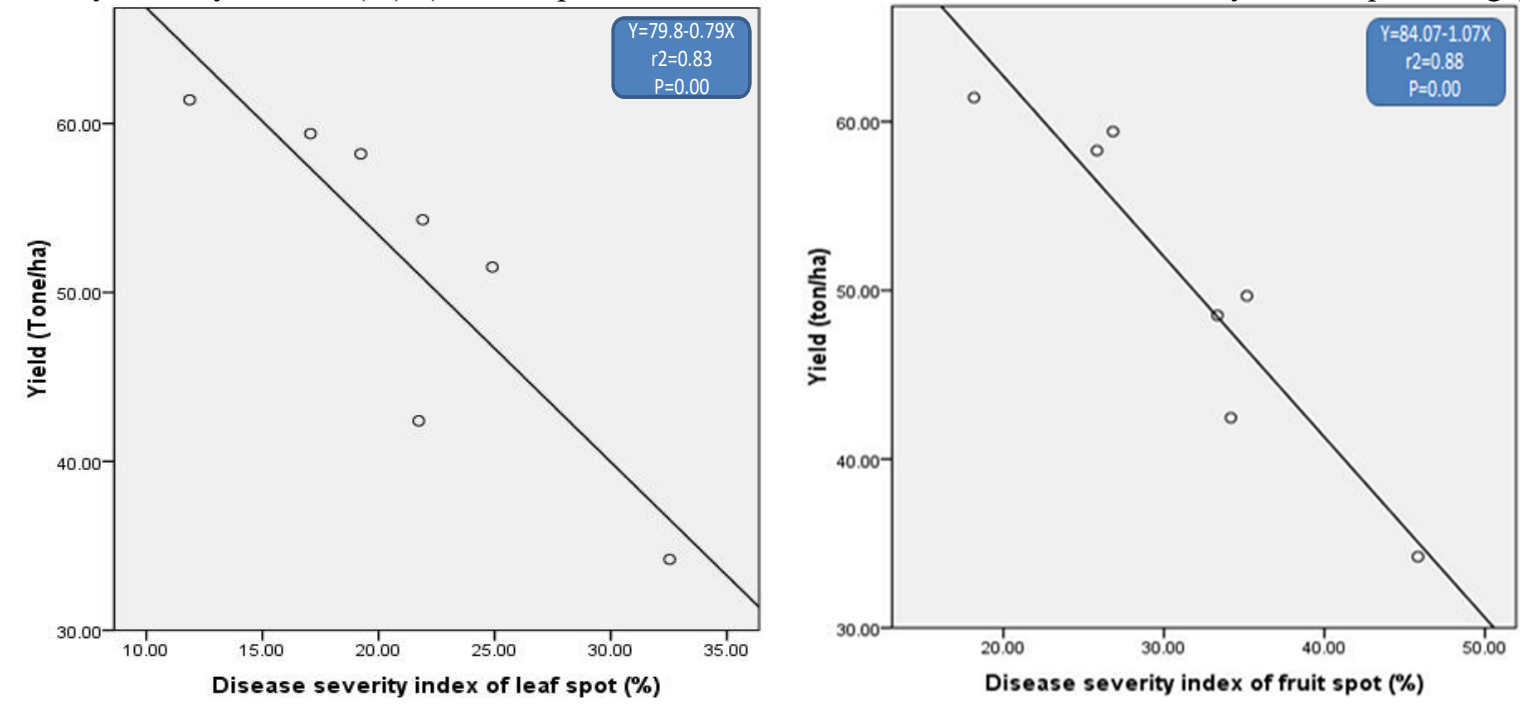

Figure 2: Linear regression of fruit yield and disease severity index leaf spot and fruit spot

\section{Cost benefit analysis}

The net benefit exhibited variation among fungicides application treated plots. Partial budget analysis was calculated based on cost of variable inputs of the year 2016 and 2017 cropping season and net benefit was estimated based on mean of local market price and farmers supplied produce to the market. The application costs used were the average price for custom application (Muraro et al., 1997) which should include not only the labor cost, but also capital expenditures and overhead. Unizeb $80 \%$ WP fungicide applied exhibited maximum partial cost benefit from all plots that means the highest (123970.00ETB ha-1) was recorded (Table 6). The Benomyl 500 WP and Benomyl $500 \mathrm{WP}+$ Unizeb 80\% WP applied fungicides plots also showed good results. The cost net benefit was recorded on Benomyl $500 \mathrm{WP}$ and Benomyl $500 \mathrm{WP}+$ Unizeb 80\% WP fungicide treated plots (111520.00 ETB ha $^{-1}$ )and (111345.00 ETB ha ${ }^{-1}$ ) (Table 6), respectively. 
Table 7: Partial budget analysis for leaf and fruit spot management of sweet orange

\begin{tabular}{|c|c|c|c|c|c|c|c|}
\hline \multirow[t]{2}{*}{ Fungicides } & \multicolumn{7}{|c|}{ General cost benefit } \\
\hline & $\begin{array}{l}\text { (A) adj. } \\
\text { yield(t.ha- } \\
\text { 1) }\end{array}$ & $\begin{array}{l}\text { (B) price } \\
\text { (ETBt-1) }\end{array}$ & $\begin{array}{l}(\mathrm{C}) \text { sale } \\
\text { revenue } \\
\left(\mathrm{A}^{*} \mathrm{~B}\right)\end{array}$ & $\begin{array}{l}\text { (D)margina } \\
1 \quad \text { cost } \\
\text { (ETBha-1) }\end{array}$ & $\begin{array}{l}\text { E)net } \\
\text { profit } \\
\text { (ETB) } \\
\text { (C-D) }\end{array}$ & $\begin{array}{l}(\mathrm{F}) \\
\text { marginal } \\
\text { benefit } \\
(\mathrm{ETB})\end{array}$ & $\begin{array}{l}\text { MRR } \\
(\mathrm{F} / \mathrm{D}) \\
(\%)\end{array}$ \\
\hline Control (no sprayed) & 3.42 & 20000 & 68400 & 0.0 & 68400 & 0.0 & 0.0 \\
\hline Trust-cymocop 439.5 WP & 4.85 & 20000 & 97000 & 2880 & 94120 & 25720 & 108.93 \\
\hline Benomyl $500 \mathrm{WP}+$ Trust-cymocop $439.5 \mathrm{WP}$ & 4.24 & 20000 & 84800 & 5080 & 79720 & 11320 & 102.23 \\
\hline Benomyl $500 \mathrm{WP}$ & 5.94 & 20000 & 118800 & 7280 & 111520 & 43120 & 105.92 \\
\hline Unizeb $80 \%$ WP + Trust-cymocop 439.5 WP & 5.43 & 20000 & 108600 & 2855 & 105745 & 37345 & 113.08 \\
\hline Benomyl $500 \mathrm{WP}+$ Unizeb $80 \%$ WP & 5.82 & 20000 & 116400 & 5055 & 111345 & 42945 & 108.49 \\
\hline Unizeb $80 \%$ WP & 6.34 & 20000 & 126800 & 2830 & 123970 & 55570 & 119.22 \\
\hline
\end{tabular}

$\overline{\text { Adj. } \text { yield }=\text { adjusted yield, } \text { ETBt }^{-1}=\text { Ethiopian birr per tons, } \text { ETBha }^{-1}=\text { Ethiopian birr per hectare, } \mathrm{MRR}=\text { marginal }}$ rate return.

\section{CONCLUSIONS}

This study results showed that levels of disease incidence was $100 \%$ on all plots and fungicides had different responses to the leaf and fruit spot disease severity of sweet orange under field conditions. The Unizeb $80 \% \mathrm{WP}$ fungicides showed lower levels of disease severity and control (unsprayed) exhibited high level of disease severity. The lowest disease severities (17.33 and $18.83 \%$ ) leaf and fruit spot disease were recorded on plots sprays treated with Unizeb $80 \% \mathrm{WP}$, respectively. The maximum fruit yields $6.14 \mathrm{t} /$ ha were obtained from Unizeb $80 \% \mathrm{WP}$ sprayed plot, followed 5.94 and $5.83 \mathrm{t} /$ ha fruit yields sweet orange which sprayed Benomyl $500 \mathrm{WP}$ and Benomyl $500 \mathrm{WP}+$ Unizeb 80\% WP, respectively. Unizeb 80\% WP fungicide applied exhibited maximum partial cost net benefit from all plots that means the highest (123970. 00 ETB ha-1) was recorded, followed by Benomyl 500 WP (111520.00 ETB ha-1) and Benomyl 500 WP + Unizeb 80\% WP (111345.00 ETB ha-1), respectively. The results of the present study revealed that the novel possibility of using Unizeb foliar spray with four times which were found to be an effective in decreasing leaf and fruit spot disease symptoms on sweet orange in Kellem Wollega, Western Oromiya and increased yield. This study could be provided some evidences on the response of sweet orange, efficacies of fungicides and its application frequencies for the disease managements and substantial increase on yield.

\section{Recommendations}

The results of the present study revealed that the possibility of using Unizeb foliar spray four times at the rate of $2.5 \mathrm{~kg}$ per hectare on threshold level and also Benomyl and Benomyl + Unizeb foliar treatments which were found to be an effective in decreasing Phaeoramularia leaf and fruit spot disease on sweet orange fruit in Kellem Wollega, Western Oromiya in Ethiopia and increased yield. Therefore, recommended for use those areas. Management options of chemical fungicides could be recommended to the farmers in Wester Oromia for this disease to control

\section{Reference}

Amadi, J.E. (2008). Studies of the etiology of leaf spot of disease of rough lemon (Citrus jambhiri-B. Jamir; H. Jhambhiri). Bio-Research 6:343-345.

Anonymous (2014), United States Department of Agriculture - Foreign Agricultural Service, Citrus: World Markets and Trade, July 2014 Report. World Agricultural Outlook Board - USDA.

CIMMYT (International Maize and Wheat Improvement Center). 1988. From agronomic data to farmers' recommendations: Economic training mannual.79 pp.

(CSA), Central Statistical Agency 2017. Report on area and production of major crops (privat peasant holdings, meher season). Statistical Bulletin, 1 (584): 13-14.

FAO (2015), FAOSTAT. Food and Agriculture Organization of the United Nations. http://faostat3.fao.org/download/Q/QC/E

Ezeibekwe, I.O. (2011). Study of citrus disease prevalence on four citrus varieties at the National Institute of Horticultural Research (NIHORT) Mbato, Okigwe, Imo State, Nigeria. African Journal of Plant Science 5:360- 364 .

Emechebe A.M., Brown spot of Citrus caused by Phaeoisariopsis sp., Ann. Appl. Biol. 97 (1981) $257-262$.

Eshetu D., Occurrence, prevalence and control methods of Phaeoramularia leaf and fruit spot disease of citrus in Ethiopia, Fruits 54 (1999) 225-232.

Jeger MJ (2004). Analysis of disease progress as a basis for evaluating disease management practices. Annu. Rev. Phytopatol. 42: 61-82

Kirk P.M., Phaeoramularia angolensis, Mycopathology 94 (1986) 177-178.

Kuate J., Citrus leaf and fruit spot disease caused by Phaeoramularia angolensis, Cah. Agric. 7 (1998) 121-129. 
Meyonga G.M., Cercospora fruit and leaf spot disease of citrus in Cameroon. Response to four fungicidal treatments, OAU/IAPSC, Doc. 71/28, Yaoundé, Cameroon, 1971

Mohammed Y. (2007), distribution and management of Phaeoramularia leaf and fruit spot disease of citrus in Ethiopia. Fruits, vol. 62, p. 99-106,

Mohammed Y. (2013), Pseudocercospora leaf and fruit spot disease of citrus: Achievements and challenges in the citrus industry: A review, Agricultural Sciences Vol.4, No.7, 324-328

Muraro, R. P., and Hebb, J. W. 1997. Budgeting Costs and Returns for Indian River Citrus Production, 1996-97. Univ. Fla. Inst. Food Agric. Sci. Econ. Info. Rep. 97:7.

Seif A. and Whittle A. (1984), Diseases of citrus in Kenya. FAO Plant Protection Bulletin, 32, 122-127.

Seif A.A., Hillocks R.J., Some factors affecting infection of citrus by Phaeoramularia angolensis, J. Phytopathol. 146 (1998) 385-391.

Seif, A.A. and Hillocks, R.J. (1999). Reaction of some citrus cultivars to Phaeoramularia fruit and leaf spot in Kenya. Fruits 54:323-329.

Singh, H. and Rao, M.V.1989. Area under the disease progress curve: Its reliability as a measure of slow rusting resistance. Plant Breeding, 103: 319-323.

Sul, H., Hwang, S.F., Chang, K.F., Conner, R.L., Xue, A.G., Warkentin, T.D., Blad, S.F. and Turnbull, G.D. 2006. Assessment of yield loss caused by Mycosphaerella blight in field pea crops in western Canada. Journal of Plant Diseases and Protection, 113 (6): 267-274.

Taylor B (2008), Fruit and Juice. In: Ashurst PR (Ed.). Chemistry and technology of soft drinks and fruit juices. Garsington Road, Oxford, UK: Blackwell publishing Ltd, pp. 392 